\title{
I3
}

FREDERICK M. DOLAN

\section{Arendt on philosophy and politics}

\section{Philosophy and politics: a central concern}

Hannah Arendt disavowed the title of "philosopher," and is known above all as a political theorist. But the relationship between philosophy and politics animates her entire oeuvre. We find her addressing the topic in The Human Condition (1958), in Between Past and Future (a collection of essays written in the early I960s), and in Men in Dark Times (another collection of essays, this one from the late sixties). It is treated in her Lectures on Kant's Political Philosophy, composed during the seventies, and also in the posthumous Life of the Mind, two of three projected volumes of which were complete when she died in 1975. Certainly, Arendt's thought cannot be understood without taking into account her deep suspicion of and equally deep commitment to philosophy in the context of political reflection. For all that, her writings on this abiding preoccupation do not gel into a systematically articulated theory or programmatic statement. Instead, they reflect Arendt's appreciation of what remained for her a "vital tension" - an enigma.

\section{Plato's trauma}

The relationship between philosophy and politics is commonly thought to be one of mutual opposition. While the task of the philosopher is to engage a rarefied circle of thinkers on abstract, conceptual problems of enduring significance, that of the politician is to engage the public at large on concrete issues of ephemeral interest. While philosophers rarely win the agreement of their colleagues - or even care to, the achievement of consensus, however fleeting, is an urgent concern of politicians. But if politics and philosophy are opposed, they are also related. There are times - during the French and American revolutions, the American Civil Rights movement, and the international protest against the American war in Vietnam, for example - when philosophical ideas inspire dramatic political action. Conversely, political 
concerns shape philosophical debates - from discussions of euthanasia and abortion to the very question of the relationship between philosophy and politics itself.

To Arendt, that relationship is neither self-evident nor easily understood. Her first examination of the subject appears in a lecture she delivered in 1954 at the University of Notre Dame, which invites careful scrutiny as her most extended single treatment of the theme. In the lecture, which was published only in I990, she formulates her basic insights into the problem and elaborates a variety of approaches that, while they were never entirely satisfactory to her, she never definitively abandoned.

To understand Arendt's approach to the problem of philosophy and politics, it is necessary to bear in mind the course of her own intellectual development. Her philosophical awakening at the age of fourteen, when the young Königsberger first read Kant, and subsequent study in the I920s with Martin Heidegger and Karl Jaspers, were inspired, as she put it, by a fierce "need to understand." Later, as a refugee in Paris and New York, Arendt rejected academic life and her study of philosophy, throwing herself for some two decades into work on behalf of Jewish refugees. The motivation for this change, she explained in an interview in I964, was political:

[A]mong intellectuals Gleichschaltung (i.e., adjusting to Nazi policy) was the rule . . . And I never forgot that. I left Germany dominated by the idea - of course somewhat exaggerated: Never again! I shall never again get involved in any kind of intellectual business. I want nothing to do with that lot. ${ }^{2}$

The academic's professional investment in ideas, Arendt suspects, leaves him a prisoner, robbing him of understanding and paralyzing him, preventing him from acting on all-too-crude facts and providing a ready source of alltoo-sophisticated rationalizations. Between philosophical ideas and political reality, Arendt sensed, lies an abyss.

Arendt could not maintain this stark rejection of philosophy indefinitely: her need to understand was too compelling. But as she noted in the Notre Dame lecture, Western political thought hinges on a seminal event:

The gulf between philosophy and politics opened historically with the trial and condemnation of Socrates, which in the history of political thought plays the same role of a turning point that the trial of Jesus plays in the history of religion. ${ }^{3}$

The condemnation of Socrates, Arendt says, "made Plato despair of polis life and, at the same time, doubt certain fundamentals of Socrates' teachings."4 This is one of Arendt's crucial insights: that the Western tradition of political philosophy is rooted in a hostility to politics, and specifically, as Arendt 
dramatically imagines it, in the bitter loss and grief of Socrates' followers after his execution at the hands of the Athenian polis. The ensuing trauma, to use a psychoanalytic term, was determinative in causing the divorce between philosophy, or thinking, and politics, which is doing or acting. It was at this point that Plato radically redefined Socrates' conception of the relationship between politics and philosophy. Henceforth, the pursuit of philosophical truth demanded a withdrawal from politics, and just political action demanded the subordination of the political to the philosophical. In this vision of Plato as the philosopher who would make politics safe for philosophy at the expense of democracy, it is difficult not to see a projection of Arendt's early disillusionment with academic life. Arendt's distress was the mirror image of Plato's: where Plato condemned politics on behalf of philosophy, Arendt condemned (Platonic) philosophy on behalf of politics.

The locus classicus of Plato's project for philosophy and politics is to be found in the middle sections of the Republic, in Books v, VI, and VII. The philosopher requires education, the quality of education is related to the quality of the state, and so, Plato gloomily concludes, a corrupt state is likely to smother the rarest philosophical souls. At best, such a state engenders critics, individuals who are in but not of their society. A state with critics is better than one without them, and critical thinking is preferable to the unexamined life, but both are inferior to the authentically philosophical life, which must eschew the falsehoods and half-truths that control public life, and turn away from the "becoming" that opposes the eternal, essential truths of "being":

The organ of knowledge must be turned around from the world of becoming together with the entire soul ... until the soul is able to endure the contemplation of essence and the brightest region of being, that is to say, that which we call the good. ${ }^{5}$

Thus transformed, the philosopher returns to the polis and reorders it in the light of his knowledge of, and desire for, the good: "when they have thus beheld the good itself they shall use it for a model for the right ordering of the state and the citizens and themselves." Relying on his superior standards, the philosopher-ruler undertakes to mold the state in accordance with ideals that his fellow citizens are incapable of grasping. For them, the "noble" lie.

Ideally, the political regime is one that accords with philosophical insight. In a corrupt regime, however, the philosopher will avoid entanglement in politics and free himself from the opinions and passions of the polis. This Platonic vision, Arendt believes, is normative for Western political thought. Stripped of its Platonic imagery, it holds that serious political thought proceeds from first principles arrived at through a purified form of reasoning, which depends not on the opinions and passions of the society in which the 
philosopher happens to live, but on universal, transhistorical principles that transcend "mere" particulars. For Platonists, this is the only means for distinguishing between political philosophy and mere ideological discourse. In other words, the very idea of political philosophy necessitates an apolitical starting-point. The gulf between philosophy and politics could hardly be more starkly rendered: philosophy demands a principled withdrawal from public life, while politics means living according to ideas that are at best halftrue and at worst false.

How should we understand Arendt's characterization of Plato's reaction to the death of Socrates? If, as she says, it occasioned a radical change in perspective, it distorted our understanding of acting and thinking by demonizing the one and glorifying the other. In reality, thinking is not as autonomous as the Platonic tradition would have it, nor acting as thoughtless. But for Plato's grief, Arendt's fable suggests, we might understand this. Is her attitude, then, predominantly nostalgic? Arendt is often accused of hankering after the lost Greek polis, but her critics are confusing nostalgia and mourning. The work of mourning, as Freud understands it, is to dissipate our attachment to a lost object. The inability to mourn, to find in the world of the living a worthy object of love, leads to melancholia, the denial of the loved object's disappearance. To mourn, on the other hand, is to face loss to experience its true extent and meaning. Arendt's celebration of a polis impossible to recover except in the imagination is an exercise in mourning in the grand style, a successful overcoming of her despair for modern intellectual life. And in casting this episode as the symptom of a trauma, Arendt is suggesting that it should spur us to find our way towards a cure - a more supple understanding of thought and action. Her intent is not to live in the past, but, by working through the death of Socrates, to prepare the inheritors of Plato's trauma for a new way to love this world, in the present.

\section{Socrates contra Plato}

In trying to imagine a non-Platonic view of the relationship between philosophy and politics, Arendt reconstructs what she regards as "the fundamentals of Socrates' teachings" as they appear outside the framework of Plato's trauma. ${ }^{7}$ Unlike the Socrates of the Republic, an embodiment of the man of thought, a Socrates who denounces democracy, celebrates pure reason and ridicules sophism, Arendt's Socrates bears a strong resemblance to the sophists. ${ }^{8}$ Arendt observes that:

If the quintessence of the Sophists' teaching consisted in the dyo logoi, the insistence that each matter can be talked about in two different ways, then Socrates was the greatest Sophist of them all. For he thought that there are, or 
should be, as many different logo $i$ as there are men, and that all these logo $i$ together form the human world, insofar as men live together in the manner of speech. ${ }^{9}$

So far from being a believer in absolute first principles, Arendt's Socrates resembles nothing so much as a liberal pluralist. For him, each member of the polis possesses his individual doxa, his opinion or viewpoint on the world, and any such doxa is to be regarded, not as a falsehood or a distortion of reality, but as a potential truth waiting to be unfolded:

To Socrates, as to his fellow citizens, doxa was the formulation in speech of what dokei moi, that is, of what appears to me. This doxa had as its topic ... the world as it opens itself to me. It was not, therefore, subjective fantasy and arbitrariness, but also not something absolute and valid for all. The assumption was that the world opens up differently to every man, according to his position in it ... ${ }^{10}$

What separates Socrates from the sophists, in Arendt's view, is his conviction that doxai contain truths, whereas for the sophists (and here, ironically, they agree with Plato) they are nothing but falsa infinita, limitless falsehoods. Arendt's Socrates does not deny the possibility of knowledge. Rather, he asserts, contra Plato's belief in the possibility of an absolute knowledge that cannot be qualified by any further experience or reflection, that a first principle can never be guaranteed. For Socrates, all such foundations - including Platonic ideas, no matter how purged of social and historical distortions are themselves subject to transformation. It is in his openness to dialegesthai, to "talk something through with somebody," that Socrates knows that he knows nothing.

Socrates is aware that anything we think we know might be wrong, and that we come to realize this when we expose our ideas to the scrutiny of others. The corollary of this position, however, is that in every opinion, some truth resides:

Every man has his own doxa, his own opening to the world, and Socrates must therefore always begin with questions; he cannot know beforehand what kind of dokei moi, of it-appears-to-me, the other possesses. He must make sure of the other's position in the common world. Yet, just as nobody can know beforehand the other's doxa, so nobody can know by himself and without effort the inherent truth of his own opinion. Socrates wanted to bring out this truth which everyone potentially possesses. ${ }^{12}$

As Arendt goes on to say, the Platonic opposition between truth and opinion is "the most anti-Socratic conclusion that Plato drew from Socrates' trial."13 Opinions are based on experience, which shapes and limits the perspective of its possessor. We come to understand the opinions of others when we grasp 
their point of view. In the realm of human affairs, reality (and so by extension, truth) is multiple.

Because he did not regard truth as inherently opposed to opinion, Socrates saw no need to make a rigorous distinction between philosophy and persuasion, the political art par excellence. "What Plato later called dialegesthai, Socrates himself called maieutic, the art of midwifery: he wanted to help others give birth to what they themselves thought anyhow, to find the truth in their doxa."14 Socratic philosophy

brings forth truth not by destroying doxa or opinion, but on the contrary reveals doxa in its own truthfulness. The role of the philosopher, then, is . . not to tell philosophical truths but to make the citizens more truthful. The difference with Plato is decisive: Socrates did not want to educate the citizens so much as he wanted to improve their doxai, which constituted the political life in which he too took part. ${ }^{15}$

Doxa, in its sense not only of opinion but also of splendor and fame, is incompatible with privacy, whereas Socrates, Arendt stresses, moved in the marketplace, "in the very midst" of doxai. ${ }^{16}$ Arendt's Socrates, unlike Plato's, does not turn away from the polis. He avoids public affairs, but does not retreat to private life.

Arendt thus chooses to emphasize Socrates' affinity with the sophists, with their concern for public opinion and their respect for dialogue and its use in the service of persuasion, controversy, and consensus. Her intent is not to play down Socrates' moral purpose, for rendering the citizens' opinions richer, sharper, and deeper helps them to become better. Her Socrates, too, is opposed to Plato's morality of individual fidelity to the natural order, as embodied in the just, philosophically grounded state - what Arendt characterizes as a "tyranny of truth, in which it is not what is temporally good, of which men can be persuaded, but eternal truth, of which men cannot be persuaded, that is to rule the city." 17 Socrates, by contrast, believes that "the role of the philosopher ... is not to rule the city, but to be its 'gadfly," "that is, to encourage citizens to think for themselves, not to be instruments of a larger natural or metaphysical order. ${ }^{18}$ For Arendt's Socrates, morality and persuasion go together, because the individual, even when alone, is always "two-in-one" insofar as he is thoughtful: in "speaking with myself I live together with myself." ${ }^{19}$ For Socrates,

living together with others begins by living together with oneself. Socrates' teaching meant: only he who knows how to live with himself is fit to live with others. The self is the only person from whom I cannot depart, whom I cannot leave, with whom I am welded together. ${ }^{20}$

Just as one needs the opinions of others to develop the truth of one's own, one must form an opinion of oneself and one's actions that is neither slav- 
ishly dependent on the prevailing doxa (as the sophists are) nor radically estranged from it (as Plato is). Diverging radically from Plato, Socrates posits solitude - that is, the cultivation of the self, or individual personality - as "the necessary condition for the good functioning of the polis, a better guarantee than rules of behavior enforced by laws and fear of punishment."21

\section{From truth versus opinion to justice versus friendship}

So far, I have described how Arendt makes philosophy friendly to politics by replacing the Platonic opposition of truth to opinion by a Socratic idea of the truth of opinion. This also allows her to redefine the traditional orientation of political philosophy toward the problem of justice. Taking Aristotle as a stand-in for Socrates, she writes:

Aristotle concludes that it is friendship not justice (as Plato maintained in the Republic, that great dialogue about justice) that appears to be the bond of communities. For Aristotle, friendship is higher than justice, because justice is no longer necessary between friends. ${ }^{22}$

Justice requires subordination to a universal principle that overrides any relationship between individuals. Talking things through in order to arrive at the truth of an opinion, on the other hand, yields no fixed result, involves give and take, and implies that friendship matters more than any particular assertion that friends might dispute. For friends, "[t]o have talked something through, to have talked about something, some citizen's doxa, [is] result enough. ${ }^{23}$ Establishing friendship among Athens's citizens is an ontological imperative, since friendship "consists of . . . talking about something the friends have in common," which over the course of time constitutes a world its own. ${ }^{24}$ As Aristotle says, "a community is not made out of equals, but on the contrary of people who are different and unequal," and who therefore rely on the exchange of opinion in friendship to "equalize" themselves. ${ }^{25}$ Socrates too, on Arendt's account, "seems to have believed that the political function of the philosopher was to help establish this kind of common world, built on the understanding of friendship, in which no rulership is needed." 26

For Arendt, Socrates' view of opinion and friendship is a far more compelling model of an authentically political philosophy than Plato's commitment to truth and justice. Plato's outlook, as I have noted, is by contrast essentially apolitical - notwithstanding his interest in politics, a subject he treats not only in the Republic but also in the Statesman, the Apology, Protagoras, Laws, and elsewhere, to say nothing of his voyage to Syracuse on behalf of his Republic. Whereas Socrates understands the relative, plural 
character of truth and can appreciate the true worth of the political, Plato, who sees truth as absolute and singular, regards with "indifference and contempt . . . the world of the city," 27 and so considers not "how philosophy looks from the viewpoint of politics but how politics, the realm of human affairs, looks from the viewpoint of philosophy." 28 Just as Socrates' insight into the intimate relation between truth and opinion gives him insight into human affairs, so Platonic dogmatism in philosophy accords with Platonic authoritarianism in politics; it attempts to subordinate the political to the philosophical, to the disadvantage of each. A properly political view of the world for Arendt is pluralistic and relativistic:

This kind of understanding - seeing the world (as we rather tritely say today) from the other fellow's point of view - is the political insight par excellence. If we wanted to define, traditionally, the one outstanding virtue of the statesman, we could say that it consists in understanding the greatest possible number and variety of realities - not of subjective viewpoints, which of course also exist but do not concern us here- as those realities open themselves up to the various opinions of citizens; and, at the same time, in being able to communicate between the citizens and their opinions so that the commonness of this world becomes apparent. ${ }^{29}$

The Platonic political philosopher is interested in his point of view only; the Socratic political philosopher tests and elaborates his perspective against others'. A Socratic philosophy of multiple perspectives, amenable to rich and surprising development, accords well with the politics of a diverse citizenry: it is democracy perfected.

\section{Wonder at being versus the tyranny of truth}

The essential medium of human affairs is speech, but the inner spring of philosophy, Arendt says, is akin to speechlessness. Referring to passages in Plato's Seventh Letter and the Theaetatus, Arendt asserts that "the beginning of philosophy is wonder." 30 She writes:

Thaumadzein, the wonder at that which is as it is, is according to Plato a pathos, something which is endured and as such quite distinct from doxadzein, from forming an opinion about something. The wonder that man endures or which befalls him cannot be related in words because it is too general for words. Plato must first have encountered it in those frequently reported traumatic states in which Socrates would suddenly, as though seized by a rapture, fall into complete motionlessness, just staring without seeing or hearing anything. ${ }^{31}$

Although she attributes this rapture to Socrates, what Arendt evidently has in mind is Martin Heidegger's “being of beings." That phrase is meant to 
capture the significance of the peculiar fact that there is something rather than nothing - that this fact makes a difference, so to speak, so that what is is meaningful not only with respect to its properties, qualities, and behavior, but as sheer, stark being. What separates the philosopher from his fellow citizens is that he is struck by the fact that he is, when he might as well never have been, or that there is anything at all, when there might as well have been nothing. Faced with this "miracle of being," the philosopher's only response is silent, speechless wonder - a state that our language, which is best suited to describing the properties, qualities, and behavior of things, is not adequate to express.

Given this experience,

[t] he philosopher ... finds himself in a twofold conflict with the polis. Since his ultimate experience is one of speechlessness, he has put himself outside the political realm in which the highest faculty of man is, precisely, speech... The philosophical shock, moreover, strikes man in his singularity, that is, neither in his equality with all others nor in his distinctness from them. In this shock, man in the singular, as it were, is for one fleeting moment confronted with the whole of the universe, as he will be confronted again only at the moment of his death. He is to an extent alienated from the city of men, which can only look with suspicion on everything that concerns man in the singular. ${ }^{32}$

If speechless wonder is the center of authentic philosophical activity, as Arendt thinks it was for Socrates, Plato, and Aristotle, philosophy becomes above all a mode of questioning - a way of posing and discussing questions that are not amenable to ordinary investigation and resolution. "As soon as the speechless state of wonder translates itself into words," Arendt writes, "it will not begin with statements but will formulate in unending variations what we call the ultimate questions - What is being? Who is man? What meaning has life? What is death? etc. - all of which have in common that they cannot be answered scientifically." 33 The only adequate "answer" to such questions is to ponder them.

In this way, Arendt says, "man establishes himself as a question-asking being." ${ }^{44}$ Stilled and silenced by wonder, speaking only to ask unanswerable questions, the philosopher will shrink from forming "opinions on matters about which man cannot hold opinions because the common and commonly accepted standards of common sense do not here apply" unlike hoi polloi, who avoid the experience of wonder, which they refuse to endure, by acquiring opinions on matters about which opinion is inadequate. ${ }^{35}$ When he does speak with others, the philosopher is likely to express his disagreement with public opinion. This was Socrates' way: he sought to engage his fellow citizens in dialogue despite the fact that his 
sense of wonder separated him from them. Plato, on the other hand, was determined to prolong wonder indefinitely - a self-defeating enterprise, Arendt argues, since it attempts "to develop into a way of life . . . what can only be a fleeting moment." 36 In his attempt to become, as it were, utterly singular, the Platonist, Arendt concludes, destroys the human plurality within himself.

Initially, Arendt stressed the conflict between the philosophical commitment to a singular truth and the multiplicity of opinions in political life. Now, she draws our attention to the medium of politics - speech - and its conflict with an experience that cannot be articulated, at least in declarative statements. The Platonic philosopher is not only disdainful of politics' disregard for truth, but unable to participate in politics owing to its affiliation with a mode of speech that will only raise questions that can be answered. Not only does the Platonic philosopher refuse the idea of a plurality of truths, but his insight into the limits of articulate understanding as such prevents him from embracing a form of life that insists that man is the measure of all things. The political gravamen of Plato's philosophy is to be found, Arendt suggests, in his image (found in Book vil of the Republic) of the cave dweller who surfaces to glimpse the sun and returns to his companions with superior knowledge, but too dazed to deal intelligently with the world underground:

The returning philosopher is in danger because he has lost the common sense needed to orient him in a world common to all, and, moreover, because what he harbors in his thought contradicts the common sense of the world. ${ }^{37}$

As Plato puts it, such a person "cuts a sorry figure and appears most ridiculous, if, while still blinking through the gloom, and before he has become sufficiently accustomed to the surrounding darkness, he is compelled . . . to contend about the shadows of justice." 38 The philosopher is as much in danger from the world as a danger to the world. His conviction that wonder is the central experience of human existence prejudices his judgment. In neglecting to cultivate Socrates' remarkable gift for both solitary wonder and friendly, questioning engagement with his fellow citizens, Arendt finds that philosophers after Plato, when they attend to politics at all, evaluate it on the basis of universal ideas - the latter are a misguided way to articulate the properly speechless wonder at the being of being. This does a disservice both to politics and to philosophy: philosophy remains blithely detached from the vagaries of human reality, and politics is given over to the formation of mere public opinion as opposed to the discovery of the truth of doxai. 


\section{Freedom and the nature of the political}

The example of Socrates suggests a powerful alternative to the Platonic understanding of the relationship between philosophy and politics. The question, for Arendt, is to discover a conception of truth and inquiry which does not lead to a hierarchical, tyrannical understanding of politics, but which remains distinctively philosophical, in the sense that it arises out of the necessarily rare experience of wonder. But that question involves another one: whether we can discover a concept of the political more faithful to the reality of political life than the distorted version bequeathed to us by the Platonic philosophical tradition. In making the paradoxical assertion that Socrates, who avoided participating in public affairs, not Plato, who was actively interested in them, is the truly political philosopher, Arendt is relying on her distinctive conception of the political. For her, the supreme value of politics is freedom, and freedom in Arendt's sense depends on plurality, spontaneity, and the open-ended, unpredictable character of interaction through speech and deed.

Just as Arendt looks to a non-Platonic Socrates for a different view of political philosophy, she turns to Periclean Athens for a non-philosophical idea of freedom. Then and there, she writes, "freedom was understood to be the free man's status, which enabled him to move, to get away from home, to go out into the world and meet other people in deed and word." ${ }^{39}$ This freedom, the freedom to appear in public, implies certain conditions: a "private sphere" (i.e., a household) that secures the necessities of life; the company of other free citizens (" $[\mathrm{t}]$ o be free meant both not to be subject to the necessity of life or to the command of another and not to be in command oneself. It meant neither to rule nor to be ruled"40); and a "public sphere," set aside for political life, "a space of appearances where [individuals can] act ... a kind of theater where freedom [can] appear." ${ }^{\prime 1}$ Freedom of this kind, Arendt points out, is neither "an attribute of thought [nor] a quality of the will." ${ }^{42}$ It is a form of action - or rather, interaction, for "what the actor is concerned with is doxa, fame - that is, the opinion of others." 43

Politics, then, is the cultivation of freedom, and freedom is a mode of action that can take place when one appears before an authentic public. A political act is above all a performance, and, as in music or dance, as opposed to the creative arts, "the accomplishment lies in the performance itself and not in an end which outlasts the activity." ${ }^{44}$ As a performance, a political act is intended to be distinctive, and so requires "for its full appearance the shining brightness we once called glory," that is, fame, which is a form of opinion. ${ }^{45}$ It is therefore in the nature of an authentic political act to stand out against the humdrum background of the everyday routine: 
Every act, seen from the perspective not of the agent but of the process in whose framework it occurs and whose automatism it interrupts, is a "miracle" - that is, something which could not be expected. If it is true that action and beginning are essentially the same, it follows that a capacity for performing miracles must likewise be within the range of human capacities. ${ }^{46}$

Political performances, however, are radically uncertain. ${ }^{47}$ The reason is that political action, for Arendt, is intimately tied to speech: "the actor, the doer of deeds, is possible only if he is at the same time the speaker of words." 48 The kind of speech appropriate to a world of opinion is persuasion, or rhetoric; that is "the specifically political form of speech . . the truly political art." 49 A political performance is "rhetorical" in the sense that it deals in probabilities, estimates, and perspectives. Its meaning and importance, therefore, are always subject to revision, as when the hero of one age becomes the villain of another, and are always in danger of falling into oblivion, as when what is said and done turns out to have been of merely topical interest. It is the miraculous quality of the act, if anything, that saves it from oblivion, because, as something great and extraordinary and inexplicable, it will always be relevant, at least so long as a sense of wonder is present.

Socrates brings philosophy and politics together by investing the faculty of wonder in the realm of human affairs. An adequate response to this specifically "human" wonder is not only sheer speechlessness, nor the bare assertion of opinions, but a unique discourse in which individuated personalities meet as equals to question one another and themselves on how the miracle appears to them. This way of being together with others is a form of political life that is faithful to both philosophical wonder and the anarchic pluralism of an authentically political society. The Socratic political thinker is apolitical, because he approaches public opinion from a distance, as something to be interrogated, justified, and improved, not merely accepted as commonsensical. As befits one who is able to experience wonder, he takes nothing for granted. Still, because he possesses no absolute knowledge against which to measure the value of public opinion, he does not feel obligated to order or manage human affairs. Politics is not central to his life, but he cannot be entirely indifferent to it, since wonder is a fleeting experience, and he must dwell for the most part in the world of common sense. But he has no reason to look upon politics with the contempt and ressentiment nursed by the Platonic political philosopher, and since he has some reason to enjoy political life, he is not as subject to the tyrannical temptations indulged by Plato and his followers. 


\section{Conclusion: philosophy and politics in modernity}

The traditional tensions between philosophy and politics are based on the opposition between wonder at being and common sense, which takes it for granted that there is something rather than nothing and proceeds to make assertions, form opinions, and organize things. From the point of view of common sense, one who is caught up in philosophical wonder is blind and dumb; from the point of view of philosophical wonder, the bustling, opinionated citizenry are even more so. Plato resolved this difficulty by recasting the state as an instrument that would guarantee the experience of wonder that he prized. Socrates' resolution of the problem is clearly more appealing to Arendt, because infinitely wiser: he accepted the fact that wonder at being is a transitory experience, and learned to express it in the more circumspect form of cultivating the little miracles that arise in the realm of human affairs.

The radically different context of the modern world undercuts the relevance of Socrates' example. With what Arendt calls "the collapse of the tradition," common sense evaporates, so that "we can no longer fall back on authentic and undisputable experiences common to all." ${ }^{50}$ Unlike Socrates,

[w]e live today in a world in which not even common sense makes sense any longer. The breakdown of common sense in the present world signals that philosophy and politics, their old conflict notwithstanding, have suffered the same fate. $^{51}$

Indeed, the destruction of common sense is prefigured by Socrates himself, especially in those Platonic dialogues that are most "Socratic," which undermine all opinions without offering a truth to replace them:

The search for the truth in doxa can lead to the catastrophic result that the doxa is altogether destroyed, or that what had appeared is revealed as an illusion ... Socrates, all his protests not to possess any teachable truth notwithstanding, must somehow already have appeared like an expert in truth. The abyss between truth and opinion, which from then on was to divide the philosopher from all other men, had not yet opened, but was already indicated, or rather foreshadowed, in the figure of this one man who, wherever he went, tried to make everybody around him, and first of all himself, more truthful. ${ }^{52}$

As Oedipus and Hamlet know, and as Friedrich Nietzsche argues, limitless inquiry can prove corrosive when the examined life turns out not to be worth living.

When the tension between common sense and the wonder at being is destroyed, we enter the bleak realm of the "social," of programmed life and scripted, poll-tested politics. In this Kafkaesque world, the suspension of what was once common sense is itself common, and hence uncannily banal. 
Socratic political philosophy loses its purchase under such circumstances, because without real political life, there is nothing for the Socratic thinker to question, no truth to be found in the doxai.

This, I believe, is the point of view from which Arendt conducts her political theorizing. In her later work, Arendt turns to Kant, among others, to explore ideas of spectatorship, imagination, judgment, and critical thought. ${ }^{53}$ As these themes suggest, thinking, for Arendt, is a powerfully individuated enterprise. Unlike Socratic political philosophy, however, this properly Arendtian political philosophy is wholly appropriate to the modern context:

To live in a political realm with neither authority nor the concomitant awareness that the source of authority transcends power and those who are in power, means to be confronted anew, without the religious trust in a sacred beginning and without the protection of traditional and therefore self-evident standards of behavior, by the elementary problems of human living-together. ${ }^{54}$

The weakening of entrenched notions of common sense offers a rare opportunity to rethink our attitudes toward philosophy and politics - although, as Arendt's verbal straining at the end of that passage suggests, we may no longer feel justified in using the traditional nomenclature.

Such rethinking, for better or worse, characterizes much of the twentieth century - in literature, poetry, music, painting, and science no less than philosophy and political theory and politics. Arendt's thought is a contribution - probably the most important any political theorist has made - to that bold reassessment of the Western tradition that we broadly call "modernism." Like that of so many of her fellow modernists, her work does not lead to a settled outlook. She never arrived at a finished view of the relationship between philosophy and politics, nor did she intend to. But her concern for the problem, a sense of its complexity and drama and stakes, suffuses her writing. For this reason, Arendt can only awkwardly be classed with mainstream political philosophers, who to the present day take the Platonic, apolitical perspective as the starting point for political reflection, or, alternatively, pursue a Socratism without wonder. Arendt is one of a select group of thinkers - Michel Foucault is another - who perceive that thinking and acting have become newly enigmatic in our time. Arendt's contribution is not to have set right the relationship between philosophy and politics, but to have shown what nourishing food for thought is to be had by reflecting on it.

\section{NOTES}

I Hannah Arendt, "What Remains? The Language Remains," in EU, p. 6. Hereafter referred to as WR.

2 WR, p. II. 
3 Hannah Arendt, "Philosophy and Politics," Social Research 57 (I990): 73. Hereafter referred to as PP.

4 PP, p. 42.

5 Plato, Republic 518d. The translation here and following is adapted from Paul Shorey, in the Loeb Classical Library edition (Cambridge, MA and London: Harvard University Press, I994).

6 Plato, Republic 540a.

7 PP, p. 72.

8 Ibid., p. 92.

9 Ibid., p. 85 .

Io Ibid., p. 80 .

II Ibid.

I2 Ibid., p. 8I.

I3 Ibid., p. 75 .

I4 Ibid., p. 8I.

I5 Ibid.

I6 Ibid.

I7 Ibid., p. 78.

I8 Ibid., p. 8I.

I9 Ibid., p. 86.

20 Ibid., pp. 86-87.

2I Ibid., p. 89.

22 PP, p. 83. Arendt's reference is to the Nichomachean Ethics. She assumes, without explanation, that "great parts of Aristotle's political philosophy, especially those in which he is in explicit opposition to Plato, go back to Socrates" (PP, p. 82).

23 PP, p. 82.

24 Ibid.

25 Ibid., p. 83.

26 Ibid., p. 84 .

27 Ibid., p. 9I.

28 Ibid., p. 96.

29 Ibid., p. 84.

30 Ibid., p. 97. The passages are at the Seventh Letter $34 \mathrm{Id}$ and the Theaetetus I $55 \mathrm{~d}$.

3 I Ibid., pp. 97-98.

32 Ibid., pp. 99-100.

33 Ibid., p. 98.

34 Ibid., p. 99.

35 Ibid.

36 Ibid., p. IOI.

37 Ibid., p. 95 .

38 Plato, Republic 5i8b.

39 Hannah Arendt, "What is Freedom?," in BPF, p. I48. Hereafter referred to as WF.

40 Arendt, $H C, 32$.

$4 \mathrm{I}$ WF, p. I54.

42 Ibid., p. I48.

43 Arendt, LKPP, p. 55 . 
44 WF, p. I 53.

$45 H C$, p. I80.

46 WF, p. I69.

47 See HC, p. 9I.

48 Ibid., p. I79.

49 PP, pp. $74-75$.

50 Hannah Arendt, "What is Authority?," BPF, p. 9I. Hereafter referred to as WA.

5I PP, pp. IO2-IO4.

52 Ibid., pp. 90-9I.

53 See LKPP and Arendt, LM, vol. I, Thinking.

54 WA, p. I4I. 